\title{
Ecotoxicity of leaf extracts of Azadirachta indica on chironomids larvae
}

\author{
J.A. Adakole* and S. Ogwu \\ Department of Biological Sciences, Ahmadu Bello University, Zaria, Nigeria \\ drjaadakole@yahoo.com
}

\begin{abstract}
The present study was designed to evaluate acute ecotoxicity of aqueous and ethanolic leaf extracts of Azadirachta indica on Chironomus spp. Exposure of chironomd larvae to the crude aqueous extract ( 0.0 [control], 25.00, 50.00, $75.00,150.00 \& 200.00 \mathrm{mg} / \mathrm{L})$ and ethanolic $(0.0$ [control], $6.00,12.00,25.00,50.00 \& 100.00 \mathrm{mg} / \mathrm{L})$ concentrations resulted in $L_{50}$ of $68.28 \mathrm{mg} / \mathrm{L}$ and of $6.65 \mathrm{mg} / \mathrm{L}$ respectively. Other toxic response by the larvae includes avoidance of sediment, impregnation of some segments with dark substances and bleaching/loss of respiratory pigments. Comparatively, mortality rate and other toxic responses was more in the ethanolic extract than in the aqueous extract test tanks. Impregnation of some larvae segments with dark substances suggests that feeding activity was going on during the toxicity test period and mortality of the larvae was partly due to contact with the polluted sediment and ingestion of contaminated particles of the sediment.
\end{abstract}

Keywords. Ecotoxicity, Azadirachta indica, Neem, chironomus larvae, Ecotoxicity

\section{Introduction}

Azadirachta indica (neem plant), family Meliaceae is known to contain a variety of compounds that show insecticidal, antifeedant growth-regulating, and development-modifying properties (Saleh \& El-Wakeil, 2007; Abdelouaheb et al., 2009). Neem plant is commonly grown for ornamental purpose and as a wind breaker. In Nigeria, during the dry season/harmattan period, large quantities of neem plant leaves and seeds could easily be found inside surrounding water bodies. According to Prance (2003) and Tarek et al. (2011), submerged leaves of plants release their active ingredients into the water body thereby polluting it. Slow moving rivers and streams that bioaccumulate leaves, barks, seeds and fruits of plants pose enormous risk to livestock and aquaculture practices (Makkar et al., 2007) and especially to aquatic macro-invertebrates (Adakole \& Balogun, 2011). Martinez \& Machado-Neo (2007), observed that aqueous extract of neem is extensively used in fish farm as alternative for the control of fish parasites and fish fry predators of Prochilodus lineatus. Winkaler et al. (2007), found that fish species exposed to various concentration of neem leaf extract, exhibited tissue damages in gill and kidney. However, in Nigeria, literature on toxicity of phytochemicals to aquatic invertebrates in the field is scanty.

Polar and non-polar extractions of neem yield 24 compounds other than azadirachtin that are of biological importance (Jacobson, 1999; Egho, 2012). These include anthraquinones, saponins, tannins, alkaloid, limonoids and meliantriol among others. Some active ingredients in Neem plant includes azadiractin and Limonoids which are toxic to over 500 species of insects including Myzus persicae (aphids) (Khalid et al., 2002, Martinez \& Machado-Neo, 2007; Egho, 2012); Culex pipiens (Abdelouaheb et al., 2009). Quadri and Narsaiah (2005) reported $\mathrm{LD}_{50}$ value of azadirachtin against Periplaneta americana as $1.5 \mathrm{mg} / \mathrm{g}$ after 24 hours. It has also been reported that the leaves of neem is potent against $C$. fatigans (wild strain). Quadri and Narasaiah (2005), also determined the $\mathrm{LC}_{50}$ of Neem leaves extract against $C$. fatigans to be $39.0 \mathrm{mg} / \mathrm{L}$. Though these $\mathrm{LC}_{50}$ differences could probably be attributed to differences in insect species as well as difference in mode of treatment, it could be concluded that azactiachtin is equally effective to both types of insects. Narqvi et al. (2006) investigated the effect of different neem fractions against white flies, Aleorolobus barodensis after 48 and 96 hours treatment and found that neem fractions were effective and toxic even after 96 hours in comparison to a synthetic insecticides called malathion. Neem seed extract at 5 percent concentration is an effective biopesticide in the management of insect pests of cowpea especially $A$. craccivora and M. sjostedti (Egho, 2012).

The midge fly larva (family Chironomidae) dominates and accounts for most of the macro invertebrates in fresh water environment (Hoffman et al., 2007; Adakole \& Balogun, 2011). The larvae have been reported to occupy a very important trophic level, being a constituent of important food item (Berg, 1995), to fauna occupying other trophic levels such as fish and birds which act as predators of macro-invertebrates. Clearly, Chironomid larvae have potential as a test species for sediments bioassay, because the greatest part of their life cycle, the larvae stage is spent in sediment (Carew et al., 2007). Not only do Chironomids respond to contaminated sediment, but they also fulfill many of the criteria for toxicity testing (ASTM, 1991). Thus the justification for using chironomid larvae as a test organism against the bioactivity of neem plant leaf's extract in this investigation. Furthermore, in Nigeria, many contaminated aquatic bodies such as creeks, creeklets, and estuaries among others are difficult terrains for benthic studies, thus many ecologists has been restrained from the survey and studies of such water bodies (Olomukoro \& Azubuike, 2009; Adakole \&
Research article

CIndian Society for Education and Environment (iSee)
"Ecotoxicity of neem extract" http://www.indjst.org
Adakole \& Ogwu Indian J.Sci.Technol. 
Balogun, 2011). Thus, the current excotoxicty investigation was conducted in a modified bioassay tank in the laboratory.

\section{Materials and methods}

All the Chironomis riparius used in this investigation were collected from the sediment along shallow pools of a slow moving stream $(0.01 \mathrm{~m} / \mathrm{sec}$.) in Zaria, by sieving sediment through a $250 \mu \mathrm{m}$ mesh size net. The sediments were collected to a depth of $1-2 \mathrm{~cm}$ from the stream stretch known to be relatively clean and free of Azadirachta indica tree population. Large pieces of debris and other macrofauna were discarded. The animals were acclimatized for 12 hours at room temperature by keeping them in de-chlorinated tap water in a tank, which was continually aerated. Mean body length and head capsule width of the larval instars of Chironomus spp. were $7.5 \pm 1.2 \mathrm{~mm}$ and $410.00 \pm 60.00$ $\mu \mathrm{m}$, respectively. The mean Chironomid wet weight was $3.70 \pm 0.65 \mathrm{mg}$. The color of the animals was red.

The sediment was washed through a $250 \mu \mathrm{m}$ meshsize sieve into a tank in order to remove any macro-fauna and large sediment particles, and then washed again through a $250-\mu \mathrm{m}$ mesh to ensure a standard particle size for the sediment in all the experiments. The sediments were stirred and rinsed three times with tap water, and then allowed to stand for 24 hours. At the end of 24-hour duration, the overlying water was poured off and the sediment placed in test containers. The leaves of $A$. indica were collected from the university town of Samaru, Zaria-Nigeria. The leaves were dried at room temperature and then powdered with a mortar and sieved to remove the fibres. $12.10 \mathrm{~g}$ and $27.30 \mathrm{~g}$ of the extract were obtained from $200.00 \mathrm{~g}$ powdered $A$. indica leaf by means of aqueous and ethanol extraction methods respectively.

$20.0 \mathrm{~g}$ of the sieved sediments were then treated, by shaking with solutions of $A$. indica leaf extract. Sediments with different concentrations of $A$. indica leaf extract were obtained through serial dilutions of the two stock (aqueous and ethanolic extracts) solutions. The mixing time was limited to 3 - 4 hours. The sediments used as the controls were treated as described above, but with dechlorinated tap water. Treated and control sediment supernatants were decanted and the test and control sediments were placed in transparent plasticglass bioassay tanks measuring: $10.00 \mathrm{~cm} \times 5.00 \mathrm{~cm} \times$ $5.00 \mathrm{~cm}$. Clean tap water was added to the containers up to $1.00 \mathrm{~cm}$ from the top to allow the sediment and water to equilibrate to test conditions and to allow suspended sediment to settle before the addition of the test animals (Adakole \& Balogun, 2011). Each set-up consisted of three replicate containers for each of the 5 concentrations, plus 2 controls. After pilot assays, the concentrations of each of the containers with aqueous extracted toxicant were 0.0 (control), $25.00,50.00,75.00$,
150.00 and $200.00 \mathrm{mg} / \mathrm{l}$ while those with ethanolic extract contained 0.00 (control), $6.00,12.00,25.00,50.00$ and $200.00 \mathrm{mg} / \mathrm{l}$ respectively.

The larval fourth-instars were separated from the stock tank on the basis of body length and head capsule width measured using a light microscope. Ten fourthinstars larvae were placed in each container. The containers were examined after 1, 12 hours and thereafter daily. Dead larval instars were removed and counted but not replaced. Following the standard ASTM (1991) and APHA (1998), two response criteria (survival and avoidance of sediment) were examined for the two $A$. indica leaf extract bioassays. The criteria for death were immobility and/or lack of reaction to a mechanical stimulus. All the bioassays were static and the test organisms were not fed during the test period. During the period of the bioassays the number of Chironomus that had avoided the sediment, either floating on the water surface or lying on top of the sediment, was also recorded daily. $L_{50}$ values were determined by log-probit regression using SPSS version $17.0 \AA$ for Windows/Microsoft Excel programme.

The $\mathrm{pH}$, dissolved oxygen, temperature and electrical conductivity of the test solution were determined before and at the end of the bioassay.

\section{Results}

The test water had a mean temperature of $25.0 \pm$ $1.81^{\circ} \mathrm{C}$, conductivity $160.22 \pm 22.11 \mu \mathrm{S}, \mathrm{pH} 6.58 \pm 1.10$ and dissolved oxygen of $6.50 \pm 0.85 \mathrm{mg} / \mathrm{l}$. Exposure of Chironomus sp to ethanolic extracts of the leaves of $A$. indica for 96 hours caused various behavourial and pathological changes. Chironomid larvae exposed to $25.00,50.00$ and $100.00 \mathrm{mg} / \mathrm{L}$ concentrations of $\mathrm{A}$. indica caused segments $5-11$ of the larvae to be heavily impregnated with dark substances. Mouth parts of the larvae in $50.00 \mathrm{mg} / \mathrm{L}$ and $100.00 \mathrm{mg} / \mathrm{L}$ concentration tanks became dark green in color.

In all the concentrations tanks, except the control and in the $6.00 \mathrm{mg} / \mathrm{l}$, there was also body decoration of the Chironomid larvae from red to pale greenish-yellow colorations; the tufted papillae, pair of tubules and the pair of fleshly tubercles (pro cerci) on the tail region turn pale. There was an attendant loss of the shining cuticular body covering, and the chironomid became flaccid at $12.00 \mathrm{mg} / \mathrm{L}$ to $100.00 \mathrm{mg} / \mathrm{L}$ concentrations tanks.

The mortality record of chronomid lavae exposed to various concentrations of ethanolic extracts of the leaves of $A$. indica is as shown on Table 1 . There was no mortality in the control. Probit analysis revealed that the LC50 value for ethanolic extracts is $6.656 \mathrm{mg} / \mathrm{L}$ at $95 \%$ confidence limit of the extracts with $2.891 \mathrm{mg} / \mathrm{L}$ and $10.180 \mathrm{mg} / \mathrm{L}$ as lower and upper limits respectively.

The body color of chironomid larvae exposed to $150 \mathrm{mg} / \mathrm{L}$ and $200 \mathrm{mg} / \mathrm{l}$ aqueous extracts
Research article

Clndian Society for Education and Environment (iSee)
"Ecotoxicity of neem extract" http://www.indjst.org
Adakole \& Ogwu Indian J.Sci.Technol. 
Vol. 5 No. 4 (Apr 2012)

ISSN: 0974- 6846

Table 1. Probit table for $96-\mathrm{h}$ exposure of chironomids larvae to ethanolic extract of Azadirachta indica leaf

\begin{tabular}{|c|c|c|c|c|c|c|c|}
\hline \multirow{2}{*}{$\begin{array}{c}\text { Conc. } \\
\text { Tanks }(\mathrm{mg} / \mathrm{L})\end{array}$} & \multirow{2}{*}{$\begin{array}{l}\text { Log of } \\
\text { Conc. }\end{array}$} & \multicolumn{2}{|c|}{ 96-h mortality } & \multirow{2}{*}{$\begin{array}{l}\text { Total observed } \\
\text { mortality }\end{array}$} & \multirow{2}{*}{$\begin{array}{l}\text { Total expected } \\
\text { mortality }\end{array}$} & \multirow[t]{2}{*}{ Residual } & \multirow[t]{2}{*}{ probability } \\
\hline & & replicate $A$ & replicate B & & & & \\
\hline Control (0) & 0 & 0 & 0 & 0 & 0 & 0 & 0 \\
\hline 6 & 0.778 & 4 & 3 & 7 & 8.343 & -1.343 & 0.417 \\
\hline 25 & 1.398 & 9 & 8 & 17 & 16.522 & 0.478 & 0.826 \\
\hline 50 & 1.699 & 10 & 9 & 19 & 18.655 & 0.345 & 0.933 \\
\hline 100 & 2.000 & 10 & 9 & 19 & 19.6 & -0.06 & 0.98 \\
\hline
\end{tabular}

concentrations of $A$. indica turned from red to faint pale yellow. Also at these two concentrations, it was observed that segments 5-8 were filled with dark particles. Furthermore, there was disintegration and eroding of the larva's retractile antennae and other sensory receptive organs on the head such as the setae, and lamellae. The percentage mortality of chironomid larvae exposed to aqueous extracts of $A$. indica is as shown in Table 2. From the probit analysis, the calculated LC50 value for the aqueous extracts is $68.28 \mathrm{mg} / \mathrm{L}$ with $55.76 \mathrm{mg} / \mathrm{L}$ and $81.78 \mathrm{mg} / \mathrm{L}$ as lower and upper limit respectively. Discussion

Table 2. Probit table for 96-h exposure of chironomids larvae to aqueous extract of Azadirachta indica leaf

\begin{tabular}{|c|c|c|c|c|c|c|c|}
\hline \multirow{2}{*}{$\begin{array}{c}\text { Conc. } \\
\text { Tanks }(\mathrm{mg} / \mathrm{L})\end{array}$} & \multirow{2}{*}{$\begin{array}{l}\log \\
\text { of } \\
\text { Conc. }\end{array}$} & \multicolumn{2}{|c|}{ 96-h mortality } & \multirow{2}{*}{$\begin{array}{c}\text { Total } \\
\text { observed } \\
\text { mortality }\end{array}$} & \multirow{2}{*}{$\begin{array}{c}\text { Total } \\
\text { expected } \\
\text { mortality }\end{array}$} & \multirow[t]{2}{*}{ Residual } & \multirow[t]{2}{*}{ probability } \\
\hline & & $\begin{array}{c}\text { replicate } \\
\text { A }\end{array}$ & $\begin{array}{c}\text { replicate } \\
\text { B }\end{array}$ & & & & \\
\hline Control (0) & 0 & 0 & 0 & 0 & 0 & 0 & 0 \\
\hline 25 & 1.398 & 1 & 0 & 1 & 0.503 & 0.497 & 0.025 \\
\hline 50 & 1.699 & 2 & 1 & 3 & 4.877 & -1.877 & 0.244 \\
\hline 75 & 1.875 & 6 & 6 & 12 & 10.631 & 1.639 & 0.518 \\
\hline 150 & 2.176 & 9 & 8 & 17 & 18.095 & -1.095 & 0.905 \\
\hline 200 & 2.301 & 10 & 10 & 20 & 19.333 & 0.667 & 0.967 \\
\hline
\end{tabular}

The physiochemical parameters of the dilution water varied but were within the range suggested by Bat \& Akubut (2001) for sustenance of aquatic life. There was no mortality, in any of the two-control set up, demonstrating that the holding facilities, water, control sediment and handling techniques were conducive for conducting 96-hour sediment testing. Thus the responses observed in the test tanks were due to the neem plant leaf's extract. Neem products have been shown to exhibit a wide range of effects such as antifeedancy (Lucantoni et al., 2006), ovicidal activity, fecundity suppression (Su \& Mulla, 1998; Abdelouaheb et al., 2009), insect growth regulation (Mordue \& Nisbet, 2000) and repellency (Okumu et al., 2007). These effects are frequently attributed to the azadirachtin contents of the products (Isman, 2006). Recent studies have also demonstrated neem-induced effects on vitellogenesis and severe degeneration of follicle cells during oogenesis in mosquitoes (Lucantoni et al., 2006).

The result obtained from this investigation indicates that both aqueous and ethanolic extracts of leaves of $A$. indica at various concentrations have significant influence on chironomids larvae. According to Verkerk \& Wright (2003), the potency of $A$. indica to induce mortality at various concentrations could be attributed to neurotoxins contained in leaf extracts of $A$. indica. This neurotoxin probably kills larvae as well as the adults' midges by disturbing the normal nervous system function and the general metabolism of the organism.

The $\mathrm{LC50}$ of $6.65 \mathrm{mg} / \mathrm{L}$ and $68.28 \mathrm{mg} / \mathrm{L}$ for ethanolic and aqueous extracts respectively indicates that ethanolic extract has higher potency than the aqueous extracts. Howatt (2003) reported that ethanolic extraction of leaves of $A$. indica enhances the extraction of saponin; a compound that is normally broken down in the digestive system and enters the blood streams as a toxin. In the blood stream, it causes the breakdown of the red blood cells, which facilitates the toxin to spread very fast (Prance, 2003). Saponin has also been reported to have caused bleaching of the reddish coloration in fish's gills (Kritzon, 2003). Thus the observed discoloration of the midge fly larvae from red to pale yellow may be due to the presence of saponin. In addition, this loss of respiratory pigment/decolouration of the chironomids' heamoglobin might have enhanced their mortality.

The avoidance of the sediment is a reflection by midge fly's inability to tolerate the toxicant. According to Hoffman et al.,(2007), burrowing by chironomids is essentially an adaptation phenomenon, which enable them escape from predators. Chironomids larvae mouthparts were tainted dark green and there was a loss of some sensory organs in concentration tanks of $100 \mathrm{mg} / \mathrm{L}$ for ethanolic extract and $150 \mathrm{mg} / \mathrm{L} \& 200 \mathrm{mg} / \mathrm{L}$ for aqueous extract. Chiromid larvae are unselective sediment feeders. They probably fed on the sediments mixed with toxicants. In addition, segments 5-10 out of the 14-number segments were filled with dark materials at the end of the 96-hour toxicity testing. This suggests that feeding activity was going on during the toxicity period and mortality of the larvae was partly due to contact with the polluted sediment and ingestion of contaminated particles of the sediment.

Neem oil had an LC50 value of $11 \mathrm{mg} / \mathrm{L}$ after 8 days, against Anopheles gambiae (Okumo et al., 2007). This value compares favorably with the LC50 value $(6.65 \mathrm{mg} / \mathrm{L})$ for ethanolic extracts but several times more potent than 
the aqueous extract LC50 value of $68.28 \mathrm{mg} / \mathrm{L}$ obtained in the present investigation. Qadri \& Narsaiah (2005) reported a 24-hour LC50 value of azadirachtin against Preriplaneta americana as $1.5 \mathrm{mg} / \mathrm{L}$. The present results indicate that organic solvent extracts have lower $\mathrm{LC}_{50}$ values than the aqueous extracts indicating its greater larvicidal activities. This result is consistent with earlier works by Wandscheer et al. (2004) and Tonk et al. (2006) who separately reported that neem seed kernel extracts are more effective against mosquitoes when prepared with hexane, ethyl ether, acetone, ethanol or methanol than aqueous preparations.

\section{Conclusion}

Both aqueous and ethanolic extracts of $A$. indica were toxic to chironomids larvae. Higher potency of ethanolic extracts was probably due to stronger extraction capacity of ethanol and the low dissolved oxygen content of the extract. Our aquatic environment had frequently been submerged with various types of leaves due to natural and man-made causes. This study elucidates the possible toxic effects of submerged leaves of Azadirachta indica on Chironomus spp. The ornamental growing of $A$. indica close to water bodies should be curtailed to avoid the destruction of important aquatic macroinvertabrates which commonly serve as food and as indicator species of aquatic stress.

\section{References}

1. Abdelouaheb A, Nassima, $R$ and Noureddine $S$ (2009) Larvicidal activity of a neem tree extract (Azadirachtin) against mosquito larvae in the Republic of Algeria. Jordan J. Bio. Sci. 2(1),15-22.

2. Adakole JA and Balogun JB (2011) Acute ecotoxicity of aqueous and ethanolic extract of leaves of Khaya senegalensis on chironomid larvae. Brazilian $\mathrm{J}$. Aquatic Sci.\& Technol..15 (2),43-47.

3. ASTM (1991) American Society for Testing and Materials. Standard guide for conducting solid-phase sediment toxicity tests with freshwater invertebrates.

4. APHA (1998) Standard methods for the examination of water and wastewater. Greenberg AE, Clesceri LS \& Eaton AD (eds), 20th edn. American Public Health Association (APHA) Inc, Washington DC.

5. Bat $L$ and Akubulut $M$ (2001) Studies on sediment toxicity bioassays using Chironomus thummi K., 1911 larvae. Turkish J. Zoo. 25, 87-93.

6. Berg HB (1995) Larval food and feeding behavior. Armittage PM. pp: 136-168.

7. Carew ME, Pettigrove V, Cox RL and Hoffmann AA (2007) The response of chironomidae to sediment pollution and other environmental characteristics in urban wetlands. Freshwater Bio. 5(1),112-145.

8. Egho EO (2012) Seeds of Neem Tree (Azadirachta indica A. Juss). Promising biopesticide in the management of cowpea insect pests and grain yield in the early cropping season at Asaba and Abraka, Delta State. Nigeria. J. Agri.Sci. 4(1), 181-189.
Vol. 5 No. 4 (Apr 2012) ISSN: 0974- 6846

9. Hoffmann AA, Carew ME and Pettigrove VP (2007) Identifying chironomids (Diptera: Chironomidae) for biological monitoring using PCR-RFLP. Bull. Entomol. Res. 93, 483-490.

10. Howatt K (2003) Azadirachta indica: one tree arsenal against pests. Pesticides Sci. 37, 34-56.

11.Isman MB (2006) Botanical insecticides, detterents and repellents in modern agriculture and an increasingly regulated world. Ann. Rev. Entomol. 51, 45-66.

12.Jacobson M (1999) Review of neem research in the United States. In: Proc. Workshop. neem's potential in pest. Locke JC \& Lawson RH (eds.).

13.Khalid AS, Naqvi SNH, Ahmad I, Tabassum R and Mohammed F A (2002) Toxicity of crude neem extracts against the late second instra larvae of Musca domestica (PCSIR Strain). Pak. J. Pharm. Sci. $4(1), 77-81$.

14. Kritzon C (2003) Fishing with poison. Environ. Toxicol \& Chem.12(5), 1180-2004.

15. Lucantoni L, Giusti F, Cristofaro M, Pasqualini L, Esposito F, Lupetti P and Habluetzel A (2006) Effects of neem extract on blood feeding, oviposition and oocyte ultrastructure in Anopheles stephensi Liston (Diptera: Culicidae). Tissue Cell. 38,361-371.

16. Makka HPS, Francis G and Becker K (2007) Bioactivity of phytochemicals in some lesser- known plants and their effects and potential applications in livestock and aquaculture production systems. J Agric. 34(7-9), 101-107.

17. Martinez CB and Machado-Neo JG (2007) Acute morphological and physiological effects of lead in the Neotropical fish Pochilodus lineatus. Comp. Biochem. Physiol. C. Toxicol. Pharmacol. 145(2), 36-44.

18. Mordue (Luntz) AJ and Nisbet AJ (2000) Azadirachtin from the neem tree Azadirachta indica: its actions against insects. Ann. Entomol. Soc. Brasil. 29, 615632.

19.Narqvi SNH, Ahmed SO and Mohammed FA (2006) Toxicity and IGR effects of two neem products against Aedes aegypti (PCSIR Strain). Pak. J. Pharm. Sci. 4 (1), 1-7.

20.Prance G (2003) The harmonious co-existence between plants and people. Compo. Biochem. Physiol. C. Toxicol. Pharmacol. 145(1), 20-54.

21. Qadri SH and Narsaiah J (2005) Effect of azadirachtin in molting process of Periplaneta americana. Indian J. Exp. Biol. 16(11), 1141-1143.

22.Okumu FO, Knols BGJ and Fillinger U (2007) Larvicidal effects of a neem (Azadirachta indica) oil formulation on the malaria vector Anopheles gambiae. Malaria J. 6, 63-71.

23. Olomukoro JO and Azubuike CN (2009) Heavy metals and macroinvertebrate communities in bottom sediment of Ekpan Creek,Warri, Nigeria. Jordan $\mathrm{J}$. Biol. Sci. 2(1), 1-8.
Research article

CIndian Society for Education and Environment (iSee)
"Ecotoxicity of neem extract" http://www.indjst.org
Adakole \& Ogwu Indian J.Sci.Technol. 
24.Saleh AS and EI-Wakeil EN (2007) Effect of neem and Diatomaceous earth against Myzus persicae and associated predators. Crop Protection. 9(4), 83-96.

25.Su T and Mulla MS (1998) Antifeedancy of neem products containing Azadirachtin against Culex tarsalis and Culex quinquefasciatus (Diptera: Culicidae). J. Vector Ecol. 23,114-122.

26. Tarek MY, Mostafa IH, Walaa AM, Mounear SA and Ahmed ZS (2011) Evaluation of biological activity of some Cupressus semprevirens L. (Diptera: Culicidae). Egypt. Acad. J. Biol. Sci. 4(1), 33 - 48.

27.Tonk S, Bartarya R, Maharaj KK, Bhatnagar VP and Srivastava SS (2006) Effective method for extraction of larvicidal component from leaves of Azadirachta indica and Artemisia annua Linn. J. Enviro.Biol. 27(1), 103-105.

28.Verkerk RHJ, Wright DJ (2003) Biological activity of neem seed kernel extracts and synthetic azadirachtin against larvae of Plutella xylostella L. Pesticides Sci. 37, 83-91.

29. Wandscheer CB, Duque JE, da Silva MAN, Fukuyama Y, Wohlke JL, Adelmann J and Fontan JD (2004) Larvicidal action of ethanolic extracts from fruit endocarps of Melia azedarach and Azadirachta indica against the dengue mosquito Aedes aegypti.Toxicon. 44(8), 829-835.

30.Winkaler EU and Santos TR (2007) Acute lethal and sublethal effects of neem leaf extract on the neotropical freshwater fish Prochilodus lineatus. Compo. Biochem. Phsiol. C. Toxicol. Pharmacol. 145(2), 36-44. 